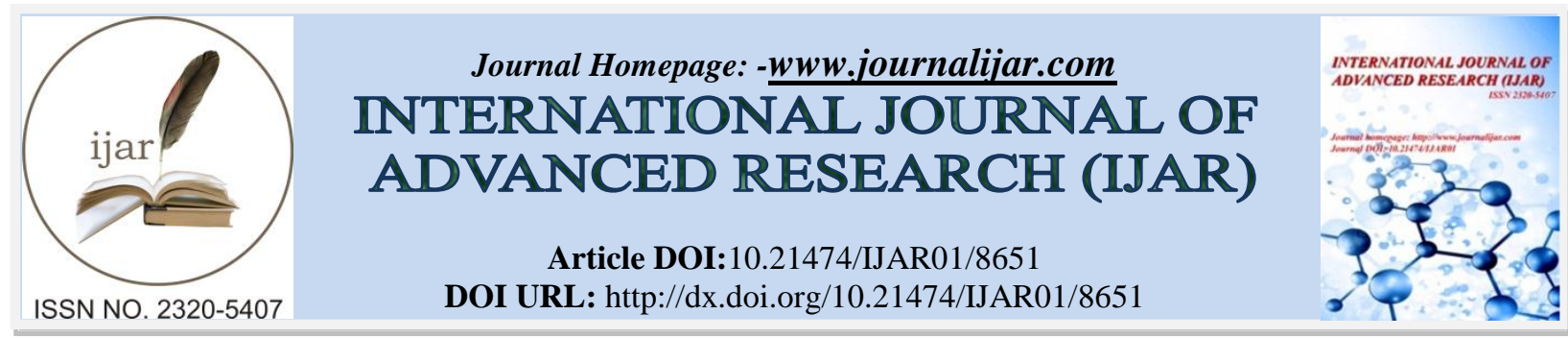

RESEARCH ARTICLE

\title{
ACADEMIC ACHIEVEMENT OF PHYSICAL EDUCATION SECONDARY SCHOOL STUDENTS IN RELATION TO THEIR INTELLIGENCE.
}

\author{
Maninder Kumar. \\ Assist.Prof, J.D. College of Education, Sri Muktsar Sahib
}

\section{Manuscript Info}

\section{Manuscript History}

Received: 09 January 2019

Final Accepted: 11 February 2019

Published: March 2019

\begin{abstract}
The present study was conducted with a view to investigate the relation in academic achievement and intelligence among physical education students of government and private schools. The sample consisted of 150 students from senior secondary schools from Muktsar city. Academic achievement scores were taken from the office report cards of the different schools and verbal intelligence test developed by R.K.Ohja and K.rayChowdhary (2005) were used. The statistical techniques like mean, SD and correlation were calculated. The result shows that there is relationship between academic achievement and intelligence and there is no significance difference between the academic achievement and intelligence on the basis of gender and type of schools.
\end{abstract}

Copy Right, IJAR, 2019,. All rights reserved.

\section{Introduction:-}

The world is becoming more and more competitive. Quality of performance has become the key factor for personal progress. It appears as if all system of education revolves around the academic achievement of students. There is general view point that intelligent is dominant in academic achievement. Academic achievement is one of the most important goals of education. It plays an important role in learning and development. Secondly, marks obtained by students are reckoned as most valuable criteria for the classification and placement of students in different classes, occupation and profession.

Parent desire that their children climb the ladder of performance to high a level as possible. This desire for a high level of achievement puts a lot of pressure on students, teachers, schools, in general the education system itself. In fact, it appears as if the whole system of education revolves round the academic achievement of students, through various other outcomes are also expected from the system.

An academic achievement is something you do or achieved at school, college or university in class, laboratory, library or field work. It helps in shaping the career of the individual and planning for future education. It encourages the students to work hard and learn more. Academic achievement plays a significant role in almost all aspect of human's life. As in science, technology and agriculture, generally the students are being selected or differentiated in the school on the basis of their academic achievement.

Intelligence an umbrella term used to describe a property of mind that encompasses many related abilities. Intelligence is the capacity to accumulate knowledge and put it into use. It is the capacity to learn or profit by 
experience. Intelligence is the ability to acquire knowledge. Due to intelligence, individuals differ from each other like bright, dull, and average. Intelligence is the global, ideal and purposeful ability integrated with many abilities like initiative talking, learning languages, numerical abstract thinking environmental adaptation and adjustment.

\section{Statement of the problem}

Academic achievement of physical education secondary school students in relation to their intelligence.

\section{Objectives of the Study}

The present study has been conducted keeping in mind the following objectives:-

1. To study the difference in academic achievement of physical education secondary school students on the basis of type of schools.

2. To study the difference in academic achievement of physical education secondary school students on the basis of type of gender.

3. To study the difference in intelligence of physical education secondary school students on the basis of type of schools.

4. To study the difference in intelligence of physical education secondary school students on the basis of type of gender.

5. To study the relationship between academic achievement and intelligence of physical education secondary school students.

\section{Hypotheses of the study}

1. There exists no significant difference in academic achievement of male and female physical education secondary school students.

2. There exists no significant difference in academic achievement of physical education secondary students of government and private schools.

3. There exists no significant difference in intelligence of male and female physical education secondary school students.

4. There exists no significant difference in intelligence of physical education secondary students of government and private schools.

5. There exist significant relationship between the academic achievement and intelligence of physical education secondary school students.

\section{Design of the study}

A descriptive survey method was employed to investigate the present study.

\section{Sample of the study}

The sample of the study consisted of random sampling pf 150 secondary school students of Muktsar city and its adjoining villages.

\section{Tools used}

1. Academic achievement scores were taken from the office records of different schools.

2. Verbal intelligence test by R.k.Ohja and K.rayChowdary (2005).

\section{Statistical techniques}

1. Pearson product moment correlation was used to calculate the relationship between the variables.

2. t-ratio was used to find the significant difference between the variables.

\section{Analysis and Interpretation}

Hypothesis 1 "There exists no significant difference in academic achievement of male and female physical education secondary school students."

Table-1:- T-ratio for academic achievement of male and female physical education secondary school students.

\begin{tabular}{|l|l|l|l|l|l|l|l|}
\hline Sr. no. & Variables & $\mathrm{N}$ & Mean & SD & S.Ed & t-ratio & Level of significance \\
\cline { 1 - 5 } & Male & 75 & 72 & 7.44 & 1.1638 & 0.5155 & $\begin{array}{l}\text { Not significant at } 0.5 \text { level and } \\
\text { at } 0.1 \text { level }\end{array}$ \\
\cline { 1 - 5 } 2 & Female & 75 & 72 & 6.80 & & & \\
\hline
\end{tabular}


The obtained ratio is lesser than the value so this hypothesis is accepted.

Hypothesis-2 There exists no significant difference in academic achievement of physical education secondary students of government and private schools.

Table-2:- T-ratio for academic achievement of Government and private secondary schools physical education students.

\begin{tabular}{|l|l|l|l|l|l|l|l|}
\hline Sr. no. & Variables & N & Mean & SD & S.Ed & t-ratio & Level of significance \\
\hline 1 & $\begin{array}{l}\text { Government } \\
\text { students }\end{array}$ & 75 & 72.6 & 7.01 & 1.164 & 0.172 & $\begin{array}{l}\text { Not significant at } 0.5 \text { level and at } \\
0.1 \text { level }\end{array}$ \\
\cline { 1 - 5 } & Private students & 75 & 72.4 & 7.25 & & \\
\hline
\end{tabular}

Obtained t-ratio is lesser than the values, so this hypothesis is also accepted.

Hypothesis-3 There exists no significant difference in intelligence of male and female physical education secondary school students.

Table -3:- t-ratio for intelligence of male and female physical education secondary school students.

\begin{tabular}{|l|l|l|l|l|l|l|l|}
\hline Sr. no. & Variables & N & Mean & SD & S.Ed & t-ratio & Level of significance \\
\hline 1 & Male & 75 & 72.1 & 17.44 & 2.52 & 0.32 & Not significant at 0.5 level and at 0.1 level \\
\hline 2 & Female & 75 & 72.9 & 13.11 & & & \\
\hline
\end{tabular}

Obtained t-ratio is lesser than the values, so this hypothesis is also accepted.

Hypothesis-4 There exists no significant difference in intelligence of physical education secondary students of government and private schools.

Table-4:- t-ratio for intelligence of Government and private secondary schools physical education students.

\begin{tabular}{|l|l|l|l|l|l|l|l|}
\hline Sr. no. & Variables & N & Mean & SD & S.Ed & t-ratio & Level of significance \\
\cline { 1 - 5 } & Government students & 75 & 71.83 & 13.09 & 2.14 & 0.5 & $\begin{array}{l}\text { Not significant at } 0.5 \\
\text { level and at } 0.1 \text { level }\end{array}$ \\
\hline
\end{tabular}

Obtained t-ratio is lesser than the values, so this hypothesis is also accepted.

Hypothesis-5 There exist significant relationship between the academic achievement and intelligence of physical education secondary school students.

Table-5:- Co-efficient correlation between academic achievement and intelligence of physical education secondary school students.

\begin{tabular}{|l|l|l|l|l|}
\hline Sr. No. & variables & N & R & $\begin{array}{l}\text { Level } \\
\text { Significance }\end{array}$ \\
\cline { 1 - 3 } 1 & Academic achievement & 150 & 0.93 & significant \\
\hline 2 & Intelligence & 150 & \\
\hline
\end{tabular}

Table shows that the correlation between the academic achievement and intelligence of physical education secondary school student is 0.93 . The obtained result holds the opinion that the academic achievement and intelligence of physical education secondary school students co relates significantly with each other.

\section{Conclusion:-}

1. There is no significant difference in the academic achievement of male and female physical education secondary school students.

2. There is no significant difference in the academic achievement of physical education government and private secondary school students.

3. There is no significant difference in the Intelligence of male and female physical education secondary school students.

4. There is no significant difference in the intelligence of physical education government and private secondary school students. 
5. There is significant relationship between the academic achievement and intelligence of physical education secondary school students.

\section{References:-}

1. Adyemio,D.a.92007). Moderating influence of emotional intelligence on the link between self efficacy and achievement of university students. Psychology and developing society,19(2).

2. Good, (1973), Foundation in education, dictionary of Education, second edition, university of Cincinnati.

3. Silverman,C. (1986). The epidemiology of depression, Baltimore, john Hopkin press.

4. Wig. N.n. (1980). Depressive illness in the North India, a review of studies done at post graduate institute of Medical education and research, Chandigarh India. 